\title{
Pengembangan Video Tutorial dalam Pelatihan Magang Kerja Siswa SMK di PT. Sinar Energi Sulawesi
}

\author{
Handy Ferdiansyah ${ }^{1}$, Zulkifli $\mathbf{N}^{\mathbf{2}}$, Nurmayanti ${ }^{3}$ \\ ${ }_{1}^{1}{ }^{2}$ Bisnis Digital/UniversitasMuhammadiyahSidenrengRappang \\ ${ }^{3}$ Teknologi Pendidikan/UniversitasMuhammadiyahSidenrengRappang \\ * Corresponding Authors. E-mail: ${ }^{1}$ handyferdiansyah888@gmail.com \\ 2zulkiflin73@gmail.com, ${ }^{3}$ mayantii57@gmail.com
}

Receive: 18/01/2021

Accepted: 28/02/2021

Published: 04/03/2021

\begin{abstract}
Abstrak
Penelitian bertujuan untuk menentukan gambaran kebutuhan media pelatihan, gambaran desain, dan validitas serta kepraktisan Pengembangan Video Tutorial dalam Pelatihan Magang Kerja Siswa SMK Di PT. Sinar Energi Sulawesi. Jenis ini merupakan penelitian dan pengembangan. Teknik pengumpulan data yang digunakan adalah teknik observasi dan angket kuesioner. Hasil penelitian ini menunjukkan bahwa penggunaan media pelatihan video tutorial dalam pelatihan magang kerja di PT. Sinar Energi Sulawesi: (i) menggambarkan perlunya media pelatihan video tutorial dalam pelatihan magang kerja siswa SMK dimulai dengan besarnya jumlah permintaan pelatihan serta terbatas waktu, jarak, dan biaya besar. memungkinkan untuk memaksimalkan hasil pelatihan, oleh karena itu perlu dibuat media pelatihan yang inovatif yakni video tutorial dalam pelatihan magang kerja. (ii) gambaran desain media pelatihan video tutorial dalam pelatihan magang kerja ini, peneliti mengadakan pertemuan dengan Tim isntruktur yang kemudian mengumpulkan materi selanjutnya membuat flowchart dan storyboard. (iii) media pelatihan video tutorial dalam pelatihan magang kerja yang dikembangkan memenuhi kriteria valid berdasarkan penilaian para ahli yaitu ahli materi dan ahli media dalam kategori Sangat Baik, sedangkan pada pengujian tingkat kepraktisan yang diperoleh dari kuisioner pelatih dan peserta pelatihan beradda dalam kategori Sangat Praktis.
\end{abstract}

Kata Kunci: pengembangan, video tutorial, validitas. kepraktisan

\begin{abstract}
The research aims to determine the description of the training media needs, design descriptions, and the validity and practicality of the Video Tutorial Development in Vocational School Student Apprenticeship Training at PT. SinarEnergi Sulawesi. This type is a research and development. The data collection techniques used were observation techniques and questionnaires. The results of this study indicate that the use of video tutorial training media in apprenticeship training at PT. SinarEnergi Sulawesi: (i) describes the need for video tutorial training media in vocational apprenticeship training for vocational students starting with the large number of requests for training and limited time, distance and large costs. allows to maximize the results of training, therefore it is necessary to create an innovative training media, namely video tutorials in apprenticeship training. (ii) an overview of the video tutorial training media design in this apprenticeship training, the researcher holds a meeting with the instructor team who then collects the material then makes a
\end{abstract}


Jurnal Edumaspul, 5 (1), Year 2021 - 117

(Handy Ferdiansyah, Zulkifli N, Nurmayanti)

flowchart and storyboard. (iii) the video tutorial training media in the developed apprenticeship training meet valid criteria based on the assessment of experts, namely material experts and media experts in the Very Good category, while the practicality level testing obtained from the trainer and training participant questionnaires is in the Very Practical category.

Keywords: development, video tutorials, validity \& practicality

\section{Pendahuluan}

Dunia kerja diera sekarang ini lebih dituntut untuk meningkatkan standar produktivitas yang ditetapkan perusahaan. Seiring pada era industi 4.0 dengan semakin tingginya dan ketatnya persaingan, baik dalam skala nasional maupun internasional, perusahaan senantiasa harus meningkatkan skill para staf atau karyawan agar hasil kerja dan semangat kerja meningkat. Sehingga dapat menekan biaya operasional dan memberi peluang yang besar kepada perusahaan untuk unggul dalam persaingan.

Pelatihan adalah proses, cara, atau kegiatan yang dilakukan untuk memberi pengetahuan atau meningkatkan kemampuan yang telah ada. Selain itu pelatihan juga merupakan suatu strategi yang sekaligus sebagai solusi untuk organisasi / perusahaan ataupun individu untuk menyesuaikan kondisi serta mengambil sebuah keputusan yang lebih efektif untuk menciptakan keunggulan daya saing. Selain itu sistem manajemen pengetahuan ialah untuk meningkatkan kompetensi atau kinerja karyawan pada organisasi / perusahaan sebagai bagian dari pengelolaan SDM.

Berkaitan dengan hal tersebut perkembangan dunia digital atau teknologi informasi dan komunikasi tidak dapat di bendung lagi, pemanfaatan teknologi sudah banyak sekali ragamnya, termasuk dalam dunia pengembangan sumber daya manusia yang bisa di jadikan sebagai media dan sumber belajar.

Di PT. Sinar Energi Sulawesi sebagai sebuah perusahaan yang sangat memperhatikan continuous improvement sumber daya manusia dalam program pengembangan dan pelatihan. Seorang administrator harus menyesuaikan jadwal pelatihan dengan jadwal pelatih dan para karyawan. Terlebih lagi, bila karyawan tersebut berdomisili luar daerah. Misalkan ada karyawan yang tinggal di luar daerah Sidenreng Rappang seperti daerah Enrekang ataupun Parepare sementara perusahaan berencana akan mengadakan sebuah pelatihan, tentunya jauh-jauh hari sebelumnya administrator dan fasilitator harus mempersiapkan transportasi dan akomodasi. Sebaliknya, bila pelatih yang diterbangkan ke daerah lain untuk melatih di sana, persiapannya tidak mudah. Ada banyak hal yang harus dipersiapkan seperti berbagai macam peralatan. Administrator pun harus mencari ruang kelas yang tersedia, mempersiapkan modul, alat tulis dan alat bantu lain di kelas atau tempat pelatihan. Dan menyiapkan konsumsi untuk karyawan. Tidak heran apabila pelatihan tidak bisa dilaksanakan dengan cepat dan efisien dan membutuhkan anggaran yang besar.

Administrator dan pengajar terus bekerja mempersiapkan pelatihan untuk memenuhi kebutuhan karyawan yang jumlahnya sangat banyak. Akibatnya mereka tidak memiliki cukup waktu untuk berhubungan kembali dengan karyawan yang telah mengikuti pelatihan sebelumnya. Mereka tidak bisa berdiskusi untuk mengetahui tindak lanjut dari hasil pelatihan, atau menjawab pertanyaan karyawan yang muncul ketika berusaha mengaplikasikan hasil pelatihan di tempat kerjanya.

Selain dari sarana dan prasarana yang menjadi penghalang, durasi waktu juga menjadi salah satu kendala dalam pelatihan kerja. Setelah ada materi atau praktik pelatihan baru yang lebih populer, mereka akan digantikan oleh orang-orang baru, yang akan mengalami nasib sama setelah beberapa waktu. Oleh karena itu, perlu inovasi dan terobosan baru dalam hal memfasilitasi pembelajaran yang sesuai 
Jurnal Edumaspul, 5 (1), Year 2021 - 118

(Handy Ferdiansyah, Zulkifli N, Nurmayanti)

dengan kondisi di lingkup PT. Sinar Energi Sulawesi. terobosan yang dimaksud pun harus sesuai dengan perkembangan zaman dan kekinian sebagai identitas utama mayoritas karyawan PT. Sinar Energi Sulawesi yang banyak memakai tenaga kerja generasi millennials. Identitas utamanya adalah penggunaan teknologi dapat ditemui dalam memenuhi kebutuhan sehari-harinya.

Berdasarkan hasil observasi peneliti pada hari 1 Juni 2020 peneliti menemukan sistem pelatihan yang dilaksanakan masih bersifat manual dimana para pekerja atau karyawan baru serta siswa SMK yang melakukan magang kerja masih berintegrasi langsung dalam artian pelatih masih lebih aktif dibanding dengan para calon karyawan serta siswa SMK yang melakukan magang kerja atau bisa disebut jika sistem pelatihan pada PT. Sinar Energi Sulawesi belum memaksimalkan teknologi yang ada. Melalui pantauan langsung tersebut serta sedikit wawancara dengan manager PT. Sinar Energi Sulawesi, sehingga peneliti bermaksud untuk mengembangkan kreativitas dan kinerja pegawai PT. Sinar Energi Sulawesi melalui pengembangan media pelatihan berbasis multimedia seperti menggunakan media video tutorial.

Menurut Cecep (2013: 64), video merupakan alat yang dapat menyajikan informasi, menjelaskan proses, menjelaskan konsep yang kompleks, mengajarkan keterampilan, mempersingkat atau memperlambat waktu dan mempengaruhi sikap. Selain itu, Firdaus dalam Utomo (2018: 69) percaya bahwa video maupun film merupakan rangkaian bingkai foto yang bergerak cepat. Dari sudut pandang di atas, dapat disimpulkan bahwa video adalah gambar real-time yang ditampilkan di layar, mampu menyajikan informasi dan menjelaskan konsep yang kompleks, ketika melihat proses secara langsung atau dengan mata telanjang, indera manusia bahkan tidak dapat menangkap konsep tersebut. Sedangkan menurut Riyana dalam Wirasasmita (2017:37) menjelaskan bahwa media video adalah media yang terdiri dari audio dan visual yang berisi pesan-pesan baik itu tentang konsep, prinsip, prosedur, teori aplikasi guna untuk membantu pemahaman.

Kamus Besar Bahasa Indonesia (2012:907) tutorial adalah pembimbingan yang dilakukan oleh pengajar atau biasa disebut dengan tutor kepada seorang atau sekelompok peserta didik. Sehingga dapat disimpulkan bahwa video tutorial merupakan sekumpulan gambar bergerak yang digunakan pengajar untuik menyampaikan pesan untuk membantu peserta didik memahami materi pembelajaran.

Setidaknya dengan penggunaan video tutorial dapat menjawab semua atau beberapa tantangan dan kesulitan yang ada di PT. Sinar Energi Sulawesi. Sebagai perusahaan yang memiliki misi operasional untuk mengembangkan sumber daya manusia yang unggul, bisnis proses secara efektif dan efisien dan juga pengelolaan keuangan yang professional dan bersih. Hal tersebutpun sudah sesuai dengan banyaknya lembaga pendidikan termasuk lembaga pelatihan perusahaan sudah mulai bertransformasi ke dunia teknologi pendidikan.

Setelah melakukan observasi dan didukung oleh beberapa teori penulis tertarik untuk meneliti permasalahan tersebut ke dalam sebuah penelitian yang berjudul: "Pengembangan Video Tutorial dalam Pelatihan Magang Kerja Siswa SMK Di PT. Sinar Energi Sulawesi".

1. Bagaimana gambaran tingkat kebutuhan media pelatihan video tutorial dalam pelatihan magang kerja siswa SMK di PT. Sinar Energi Sulawesi ?

2. Bagaimana gambaran desain media pelatihan video tutorial dalam pelatihan magang kerja siswa SMK di PT. Sinar Energi Sulawesi ?

3. Bagaimana tingkat validitas dan kepraktisan media pelatihan video tutorial yang dikembangkan dalam pelatihan magang kerja di PT. Sinar Energi Sulawesi ? 


\section{Metode}

Penelitian ini menggunakan metode penelitian dan pengembangan (Research and Development) atau lebih dikenal dengan R\&D. Menurut Putra (2015:2) R\&D adalah metode penelitian yang secara sengaja, sistematis, bertujuan/diarahkan untuk mencari temuan, merumuskan, memperbaiki, mengembangkan, menghasilkan, menguji keefektifan produk, model, metode,strategi/cara, jasa, prosedur tertentu yang lebih unggul, baru, efektif, efisien, produktif, dan bermakna.

Peneliti memilih model penelitian dan pengembangan media pelatihan video tutorial di PT. Sinar Energi Sulawesi berdasarkan analisis kebutuhan pengembangan media pelatihan, yang dipilih adalah model pengembangan ADDIE karena model pengembangan ADDIE merupakan model pengembangan yang lebih sederhana, mudah dipelajari, dan menggunakan struktur yang sistematis dibanding dengan model pengembangan lainnya. Menurut langkah-langkah pengembangan produk, model penelitian dan pengembangan ini lebih rasional dan lebih lengkap daripada model lainnya seperti 4D ataupun ASSURE. Namun berhubungan dengan tujuan penelitian yang ingin mengetahui validitas dan kepraktisan media media pelatihan video tutorial di PT. Sinar Energi Sulawesi, maka hanya akan sampai pada tahapan pengembangan (development). Peneliti mengambil tempat penelitian di lokasi PT. Sinar Energi Sulawesi. Salah satu perusahaan yang bergerak dibawah naungan PT Pertamina. Penelitian ini dilaksanakan pada bulan Juni tahun 2020 sampai dengan bulan Oktober tahun 2020.

Subjek pada penelitian ini adalah akademisi atau dosen ahli media pembelajaran dari program studi Bisnis Digital Universitas Muhammadiyah Sidenreng Rappang yaitu bapak Zulkifli N, S.Pd., M.Pd., satu praktisi ahli materi dan pelatih dari PT. Sinar Energi Sulawesi, yaitu bapak Zainal Abidin, S.Pd. serta karyawan dan siswa SMK magang kerja
PT. Sinar Energi Sulawesi sebanyak 20 (dua puluh) orang. Objek pada penelitian adalah pengembangan media pelatihan video tutorial dalam pelatihan magang kerja di PT. Sinar Energi Sulawesi.

Prosedur penelitian ini mengadaptasi model pengembangan ADDIE, yaitu model pengembangan yang terdiri dari lima tahapan meliputi analisis (analysis), desain (design), pengembangan (development), implementasi (implementation), dan evaluasi (evaluation). Namun berhubungan dengan tujuan penelitian yang ingin mengetahui validitas dan kepraktisan media pelatihan video tutorial dalam pelatihan kerja di PT. Sinar Energi Sulawesi, maka hanya akan sampai pada tahapan pengembangan (development). Instrumen yang akan diuji coba adalah lembar angket validitas dan kepraktisan media pelatihan video tutorial dalam pelatihan kerja di PT. Sinar Energi Sulawesi. Adapun ujicoba yang akan dilaksanakan meliputi Uji validitas dan uji kepraktisan.

Seluruh data yang didapatkan dari validator diolah dan dianalisis menggunakan menggunakan rumus sebagai berikut:

Persentase $=$

$\frac{\left.\sum \text { (jawaban } \mathrm{x} \text { bobot tiap pilihan }\right)}{n \times \text { bobot tertinggi }} \times 100 \%$

Sumber: Arismunandar, (2015)

Untuk mengetahui kriteria kualifikasi penilaian berdasarkan (Arikunto, 2010), yang ditunjukkan pada tabel berikut ini:

Tabel 1Rentang persentase analisis validitas produk

\begin{tabular}{|c|c|c|c|}
\hline & $\begin{array}{c}\text { Rentang } \\
\text { persentase } \\
(\%)\end{array}$ & Kwalifikasi & Keterangan \\
\hline 1 & $\begin{array}{l}81- \\
100 \%\end{array}$ & $\begin{array}{l}\text { Sangat } \\
\text { baik }\end{array}$ & $\begin{array}{l}\text { Sangat valid, tidak } \\
\text { perlu direvisi }\end{array}$ \\
\hline 2 & $61-80 \%$ & Baik & $\begin{array}{l}\text { Valid, tidak perlu } \\
\text { direvisi }\end{array}$ \\
\hline 3 & $41-60 \%$ & $\begin{array}{l}\text { Cukup } \\
\text { baik }\end{array}$ & $\begin{array}{l}\text { Cukup valid, perlu } \\
\text { direvisi }\end{array}$ \\
\hline 4 & $21-40 \%$ & $\begin{array}{l}\text { Kurang } \\
\text { baik }\end{array}$ & $\begin{array}{l}\text { Tidak valid, perlu } \\
\text { direvisi }\end{array}$ \\
\hline 5 & $<20 \%$ & $\begin{array}{l}\text { Sangat } \\
\text { kurang } \\
\text { baik }\end{array}$ & $\begin{array}{l}\text { Sangat tidak valid, } \\
\text { perlu direvisi }\end{array}$ \\
\hline
\end{tabular}


Jurnal Edumaspul, 5 (1), Year 2021 - 120

(Handy Ferdiansyah, Zulkifli N, Nurmayanti)

Adapun pada tahap uji tingkat kepraktisan, karyawan dan pelatih dilibatkan sebagai responden yang akan menjadi penilai pada proses pengujian atau uji coba media yang dikembangkan. Respon atau penilaian diperlukan langsung dari karyawan dan pelatih selaku responden untuk memperoleh data yang akan dijadikan sebagai dasar guna untuk mengetahui tingkat kepraktisan produk. Pada proses uji coba produk ini terdiri dari tiga tahap yaitu uji coba perorangan, uji coba kelompok kecil, dan uji tanggapan pelatih.

Semua data yang diperoleh dari responden, akan segera dianalisis dengan menggunakan teknik deskriptif presentase menggunakan rumus berikut:

Persentase $=\frac{\sum \mathrm{x}}{S M I} \times 100 \%$

Ket:

$\sum \mathrm{x} \quad=$ Jumlah skor

SMI = Skor Maksimal Ideal

Sumber: Tegeh (2014)

Tabel 2 Tingkat pencapaian dan kriteria

\begin{tabular}{ccl}
\multicolumn{3}{c}{ produk } \\
\hline No & $\begin{array}{c}\text { Tingkat } \\
\text { pencapaian }\end{array}$ & \multicolumn{1}{c}{ Kriteria } \\
\hline 1 & $81 \%-100 \%$ & Produk sangat praktis \\
\hline 2 & $61 \%-80 \%$ & Produk praktis \\
\hline 3 & $41 \%-60 \%$ & Produk cukup praktis \\
\hline 4 & $21 \%-40 \%$ & Produk kurang praktis \\
\hline 5 & $0 \%-20 \%$ & Produk tidak praktis \\
\hline
\end{tabular}

Sumber: Akbar (2017)

\section{Hasil dan Pembahasan}

Peneliti mengambil tempat penelitian di PT. Sinar Energi Sulawesi. Salah satu perusahaan swasta yang berada dibawah naungan PT. Pertamina. Kantornya beralamat di Poros Rappang Enrekang desa Mario Kecamatan Kulo Kabupaten Sidenreng Rappang, Sulawesi-Selatan. Peneliti sendiri melakukan observasi dan pengamatan, menganggap bahwa sistem pelatihan masih bersifat konvensional atau lebih sederhananya adalah dilaksanakan di dalam ruang kelas dengan metode ceramah sedikit ice breaking tanpa adanya media pelatihan yang berbasis teknologi sedangkan sekarang sudah masuk di era industri 4.0, sehingga luaran dari peserta pelatihan masih minim ditambah dengan biaya yang tidak sedikit. Penelitian ini dilaksanakan pada bulan Juni tahun 2020 sampai dengan bulan Oktober tahun 2020.

Selama proses penelitian dibagi berdasarkan prosedur-prosedur pengembangan yaitu analysis dan design serta development. Pada penelitian ini tidak sampai pada proses implementation dan evaluasi dikarena hanya pada tahap percobaan kelas terbatas atau untuk mengetahui kepraktisan dan kevalidan media pelatihan video tutorial dalam pelatihan magang kerja di PT. Sinar Energi Sulawesi.

Pengembangan media pelatihan video tutorial dalam pelatihan magang kerja di PT. Sinar Energi Sulawesi, berawal dari analisis terhadap kebutuhan peserta pelatihan. Observasi dilaksanakan pada bulan 1 Juni 2020. Berdasarkan dari hasil observasi tersebut ditemukan jika selama ini pelatih menyampaikan materi pelatihan dengan metode klasik (ceramah) dalam artian kurang memaksimalkan teknologi yang ada. Para peserta pelatihan dinilai masih kurang antusias dalam mengikuti pelatihan. Mereka umumnya memberikan masukan melalui kuesioner yang telah disebar tersebut dengan kesimpulan bahwa pelatihan akan lebih menyenangkan jika melibatkan media pelatihan yang lebih inovatif serta interaktif sesuai dengan perkembangan zaman saat ini, apalagi saat sekarang ini dimana sudah masuk di era industri 4.0. Selain dari itu penggunaan waktu yang cukup lama dan biaya pelaksanaan pelatihan yang tidak sedikit. Oleh karena itu, dunia pendidikan dan pelatihan memerlukan cara baru untuk menjawab tantangan tersebut. Mereka membutuhkan sentuhan teknologi yang dapat meningkatkan kwalitas pendidikan dan pelatihan yang pengadaannya cepat, metodenya lebih efektif, dan persiapannya lebih singkat. 
Salah satu produk integrasi teknologi informasi ke dalam dunia usaha adalah penggunaan media video tutorial. Saat ini video tutorial mulai mengambil perhatian banyak pihak, baik dari kalangan akademik, profesional, perusahaan maupun industri. Video tutorial merupakan salah satu dari sekian banyaknya media pembelajaran dan pelatihan yang dapat digunakan baik pada ranah pendidikan keluarga ataupun lingkungan sekitar. Saat ini media video tutorial dapat dikatakan sebagai salah satu paradigma baru dalam bidang pendidikan modern dan sudah banyak penelitian memperlihatkan bukti empiris dalam mendukung gagasan memanfaatkan teknologi video tutorial secara efektif dapat memberikan banyak peluang.

Pengadaan satu pelatihan, seorang administrator harus menyesuaikan jadwal pelatihan dengan jadwal pelatih dan para karyawan. Terlebih lagi, bila karyawan tersebut tersebar di kantor-kantor cabang lainnya yang berencana akan mengadakan sebuah pelatihan, tentunya jauh-jauh hari sebelumnya administrator dan fasilitator harus mempersiapkan transportasi dan akomodasi. Sebaliknya, bila pelatih yang diterbangkan ke kantor-kantor cabang untuk melatih di sana, persiapannya tidak mudah. Ada banyak hal yang harus dipersiapkan di kantor-kantor cabang. Administrator pun harus mencari ruang kelas yang tersedia, mempersiapkan modul, alat tulis dan alat bantu lain di kelas. Dan menyiapkan konsumsi untuk karyawan. Tidak heran apabila pelatihan tidak bisa dilaksanakan dengan cepat dan efisien dan membutuhkan anggaran yang besar.

Administrator dan pengajar (pelatih) terus bekerja mempersiapkan pelatihan untuk memenuhi kebutuhan karyawan yang jumlahnya sangat banyak. Akibatnya mereka tidak memiliki cukup waktu untuk berhubungan kembali dengan karyawan yang telah mengikuti pelatihan sebelumnya. Dari segi kebutuhan tersebut dan didukung bukti empirisnya maka diketahui gambaran kebutuhan pengembangan media pelatihan video tutorial di PT. Sinar Energi Sulawesi.

Video tutorial merupakan salah satu media elektronik yang bersifat audio visual dimana terdapat tampilan gambar dan suara. Saat ini video tutorial dianggap sebagai paradigma baru dalam bidang pendidikan modern dan sudah banyak penelitian memperlihatkan bukti empiris dalam mendukung gagasan memanfaatkan teknologi video tutorial secara efektif dapat memberikan banyak peluang dan manfaat.

Setelah mengetahui permasalahan yang dihadapi peserta pelatihan dan potensi yang ada, peneliti melakukan meeting dengan pelatih yang juga adalah kepala bidang terkait kompetensi yang sesuai sebagai bahan materi pada pengembangan media pelatihan kerja yang di rencanakan. Sesuai dengan yang pelatih ajarkan, maka dipilihlah materi pelatihan dengan kompetensi prosedur keselamatan dan kesehatan kerja di perusahaan hal ini sesuai dengan kebutuhan materi untuk karyawan baru. Peneliti merancang format media yang dibuat mulai penyusunan materi. Pada proses menyusun bahan pelatihan, peneliti cukup menggunakan Microsoft Word. Kemudian untuk pembuatan media, peneliti bekerja sama dengan beberapa anggota tim senior karyawan PT. Sinar Energi Sulawesi.

Pada tahap ini peneliti mulai merancang desain produk, dari persiapan alat dan bahan. Agar gambaran mengenai media yang akan dikembangkan terlihat jelas kita menggunakan kamera yang mendukung format video kualitas tinggi seperti mendukung format video HD. Selanjutnya merancang flowchat \& storyboard untuk keperluan media pelatihan.

Pembuatan objek media pembelajaran dilakukan dengan menggunakan perangkat keras (hardware) dan perangkat lunak (software). Hardware minimum yang diperlukan adalah komputer atau laptop serta camera recorder. Media video tutorial yang dikembangkan memenuhi kriteria kevalidan berdasarkan penilaian para ahli. Hasil validasi dari validator ahli materi 
Jurnal Edumaspul, 5 (1), Year 2021 - 122

(Handy Ferdiansyah, Zulkifli N, Nurmayanti)

terkait media yang dikembangkan menunjukkan bahwa media pelatihan yang dikembangkan berdasarkan nilai aspek kesesuaian materi, relevansi materi, ketepatan judul dengan isi materi, kelengkapan materi, kejelasan materi, kesesuaian antara gambar /ilustrasi dan materi, serta kemudahan operasional memperoleh total skor 43 dengan pencapaian $95 \%$ dan termasuk kategori "Sangat Baik" yang berarti bahwa materi yang terkandung dalam media video tutorial pelatihan kerja yang dikembangkan "Sangat Valid", dan tidak perlu direvisi untuk diujicobakan.

Untuk hasil validasi media yang dilakukan oleh validator ahli media memperoleh hasil diperoleh total skor 96. Selanjutnya nilai tersebut diubah kedalam persentase dan mendapatkan skor $96 \%$. Dari nilai tersebut diketahui bahwa tingkat pencapaian hasil validasi media pembelajaran diperoleh hasil $96 \%$ (tingkat pencapaian $81 \%$ - 100\%) menunjukkan bahwa media pembelajaran berada pada kualifikasi sangat baik yang artinya produk media video tutorial peltihan yang dikembangkan sangat valid.

Kepraktisan produk yang dihasilkan didapatkan dari hasil analisis lembar penilaian pelatih dan penilaian peserta pelatihan dalam hal ini karyawan. Hasil penilaian peserta pelatihan terhadap media video tutorial pelatihan magang kerja siswa SMK PT. Sinar Energi Sulawesi yang telah dikembangkan dan berdasarkan tabel 2 mengenai konversi skor, diketahui bahwa rata-rata skor mencapai $90 \%$. termasuk dalam kategori "Sangat praktis" untuk digunakan.

Kesimpulannya, media pelatihan video tutorial dalam pelatihan magang kerja siswa SMK di PT. Sinar Energi Sulawesi terkhusus materi prosedur keselamatan dan kesehatan kerja termasuk dalam kategori "Sangat Baik".

\section{Kesimpulan}

Gambaran kebutuhan media pelatihan video tutorial dalam pelatihan magang kerja siswa SMK di PT. Sinar Energi Sulawesi dimulai dengan banyaknya permintaan pelatihan dibeberapa unit atau anak perusahaan di PT. Sinar Energi Sulawesi namun dengan keterbatasan waktu, jarak dan biaya yang besar tidak memungkinkan untuk memaksimalkan hasil pelatihan, olehnya itu perlu untuk membuat suatu inovasi media pelatihan berbasis teknologi yaitu video tutorial.

Gambaran desain media pelatihan video tutorial dalam pelatihan magang kerja siswa SMK di PT. Sinar Energi Sulawesi dengan perancangan khusus yang dilakukan langsung dengan melibatkan instuktur atau pelatih dalam perancangan tersebut. Sebelum membuat desain media pelatihan video tutorial dalam pelatihan magang kerja siswa SMK di PT. Sinar Energi Sulawesi peneliti melakukan meeting dengan pelatih dan admin yang selanjutnya dibuatkan flowchart \& storyboard. Dari sini akan dibuatkan gambaran kebutuhan penggunaan media video tutorial pelatihan. Di PT. Sinar Energi Sulawesi selain menjadi media pelatihan seperti memberikan materi, evaluasi dan respon, rencananya juga akan menjadi media pembelajaran pelatihan berbasis digital.

Media pelatihan video tutorial pelatihan magang kerja siswa SMK di PT. Sinar Energi Sulawesi yang dikembangkan memenuhi kriteria kevalidan berdasarkan penilaian para ahli yaitu ahli materi dan ahli media dengan kategori Sangat Baik, sedangkan kepraktisan produk yang dihasilkan didapatkan dari hasil analisis lembar penilaian pelatih dan penilaian peserta pelatihan dengan kategori Sangat Praktis.

\section{Daftar Pustaka}

[1] Akbar, Sa'dun. 2017. Instrumen Perangkat Pembelajaran cetakan kelima. Bandung: PT Remaja Rosdakarya.

[2] Arikunto, Suharsimi 2010. Prosedur Penelitian Suatu Pendekatan Praktik. Jakarta: Bumi Aksara. 
[3] Arismunandar \& Nurhikmah H. 2015. Pengembangan Model Pelatihan Mbs Bagi Kepala Sekolah. Proceeding. Scientific Forum-Faculty of Education Departement of Science Education (FIP-JIP) and The International Seminar.

[4] Cecep, Kustandi \& Bambang Stjipto. 2013. Media Pembelajaran Manual \& Digital. Edisi Kedua. Bogor: Ghalia Indonesia.

[5] Putra, Nusa. 2015. Research \& Development Penelitian dan Pengembangan. Jakarta: PT Raja Grafindo Persada.

[6] Tegeh, I Made, dkk. 2014. Model Penelitian Pengembangan. Singaraja: Grzaha Ilmu.

[7] Utomo, Adhi Yoga. 2018. Pengembangan Video Tutorial Dalam Pembelajaran Sistem Pengapian Di SMK. Jurnal Taman Vokasi. Volume 6, Nomor 1, Juni 2018 (Hal. 68 - 76)

[8] Wirasasmita, Rasyid Hardi. 2017. Pengembangan Media Pembelajaran Video Tutorial Interaktif Menggunakan Aplikasi Camtasia Studio dan Macromedia Flash. EDUMATIC: Jurnal Pendidikan Informatika. Volume 1, Nomor 2.

[9] Tim Pustaka Phoenix. 2012. Kamus Besar Bahasa Indonesia (cetakan keenam). Jakarta: PT. Media Pustaka Phoenix.

\section{Profil Penulis}

Penulis pertama yaitu Handy Ferdiansyah, S.Pd., M.Pd. penulis lahir di Ujung Pandang, 01 Januari 1988. Menetap di Sidereng Rappang. Pendidikan Sarjana (S1) ditempuh penulis di Sekolah Tinggi Keguruan dan Ilmu Muhammadiyah Rappang Program Studi Teknologi Pendidikan. Pada jenjang Magister (S2), penulis melanjutkan pendidikan di Universitas Negeri Makassar dengan prodi Teknologi Pendidikan. Saat ini penulis tercatat sebagai dosen di Universitas Muhammadiyah Sidenreng Rappang.

Penulis kedua Zulkifli N, S.Pd., M.Pd. penulis lahir di Ciro-ciroe, 27 juni 1993. Pendidikan sarjana ditempuh penulis di Sekolah Tinggi Keguruan dan Ilmu Muhammadiyah Rappang Program Studi Teknologi Pendidikan dan selesai pada tahun 2016. Pada jenjang magister, penulis melanjutkan pendidikan di Universitas Negeri Makassar dengan prodi Teknologi Pendidikan selesai pada tahun 2020. Saat ini penulis tercatat sebagai dosen di Universitas Muhammadiyah Sidenreng Rappang.

Penulis ketiga yaitu Nurmayanti, S.Pd., M.Pd. penulis lahir di Rappang, 11 Desember 1994. Pendidikan sarjana ditempuh penulis di Universitas Negeri Makassar Program Studi Pendidikan Teknik Informatika dan Komputer. Pada jenjang magister, penulis melanjutkan pendidikannya di Universitas Negeri Makassar dengan prodi Pendidikan Teknologi dan Kejuruan. Saat ini penulis tercatat sebagai dosen di Universitas Muhammadiyah Sidenreng Rappang. 